\title{
Taxonomy, functional morphology, and behavioral ecology of the planktonic calanoid copepod Tortanus (Atortus)
}

\section{Susumu Ohtsuka, Mohsen M. El-Sherbiny, and Hiroshi Ueda}

Abstract.-Two new species of Tortanus (Atortus), T. (A.) ampliramus and $T$. (A.) nishidai, are described from the northern Red Sea and the Gulf of Aden, respectively. These new species evidently belong to the recticauda species group in the recticauda species complex. The species group has a distinct distribution in the western Indian Ocean, extending from South Africa. The functional morphology of spermatophores of Tortanus is also discussed. A semelparous reproductive strategy may be employed in some species of Tortanus, whereas others adopt an iteroparous strategy as do most of centropagoideans. The formation of swarms was found exclusively in the subgenus Atortus which inhabits clear waters. Swarms of $T$. (A.) erabuensis may utilize swarms of another small copepod, Oithona oculata as prey.

\section{Introduction}

The calanoid copepod genus Tortanus Giesbrecht, 1898 accommodates 31 nominal species, and is broadly distributed in neritic/brackish waters in the Indo-West Pacific and the northwestern Atlantic (Ohtsuka \& Reid, 1998; Chen \& Hwang, 1999). In the genus, five subgenera have been hitherto recognized, and each has a restricted distribution (Ohtsuka \& Reid, 1998): T. (Tortanus) Giesbrecht, 1898 in the Indo-West Pacific; T. (Eutortanus) Smirnov, 1935 in East Asia; T. (Actanus) Ohtsuka, 1992 in the northwestern Atlantic; T. (Atortus) Ohtsuka, 1992 in the Indo-West Pacific; and T. (Boreotortanus) Ohtsuka \& Reid, 1998 in the North $\mathrm{Pa}$ - cific and the northwestern Atlantic (Ohtsuka \& Reid, 1998). The phylogeny and evolutionary history of these subgenera are analyzed in detail by Ohtsuka \& Reid (1998).

A new species belonging to the subgenus Atortus was discovered from the northern Red Sea during periodical plankton sampling by the second author. Another new species of this subgenus was collected from the Gulf of Aden, which had previously been reported as $T$. (A.) sp. (Ohtsuka \& Kimoto, 1989). The subgenus Atortus is provisionally divided into two species complexes and four species groups (Ohtsuka \& Kimoto, 1989).

The present paper deals with descriptions of the two new species, the functional morphology of spermatophores, and behavioral ecology of the subgenus Atortus.

\section{Materials and Methods}

One new species from the northern Red Sea was collected from a shallow bay (3-9 $\mathrm{m}$ in depth) called "Sharm El-Maya" $\left(27^{\circ} 51.39^{\prime} \mathrm{N}, 34^{\circ} 17.53^{\prime} \mathrm{E}\right)$ on March 27 , 1995, with a plankton net (mesh size 0.1 $\mathrm{mm}$ ). The salinity ranged from 40.5 to 41.5 ppt. Another new species was captured from shallow water (5 $\mathrm{m}$ in depth) in the Gulf of Aden $\left(13^{\circ} 5^{\prime} \mathrm{N}, 46^{\circ} 35^{\prime} \mathrm{E}\right)$ on December 18, 1979 with a plankton net (mesh size $0.1 \mathrm{~mm}$ ) (Nishida, leg.). Copepods were fixed in neutralized formalin/ sea-water, and then preserved in $70 \%$ ethanol. The type specimens are deposited at the Natural History Museum, London (NHM). Terminology follows Huys \& 
Boxshall (1991).

Underwater observations and collection of swarms of Tortanus (Atortus) erabuensis Ohtsuka, Fukuura \& Go, 1987 were carried out in a small inlet of Kuchinoerabu Island, the Nansei Islands, southwestern Japan, during the daytime on September 7, 1989 by skin and SCUBA diving. Before collection, the size and shape of the swarms were recorded. Swarming copepods were captured in several tows using an opening-closing handheld net (diameter $30 \mathrm{~cm}$; mesh size 0.1 $\mathrm{mm}$ ), and then preserved by neutralized formalin/sea-water. Copepods were counted according to developmental stage and sex. The present paper briefly reports the swarms of $T$. (A.) erabuensis as details (Ohtsuka et al., unpublished data) will be published elsewhere.

\section{Taxonomy}

\section{Tortanus (Atortus) ampliramus new species}

Figs. 1, 2

Material examined.-7 $9 \subsetneq \& 5$ 荥, Sharm El-Maya $\left(27^{\circ} 51.39^{\prime} \mathrm{N}, 34^{\circ} 17.53^{\prime} \mathrm{E}\right)$ in the northern Red Sea, March 27, 1995.

Types.-Holotype: 1 \&, partly dissected and mounted on glass slides, NHM-2000.2058. Paratypes: 2 ㅇ \& 2 $\delta \delta$, partly dissected and mounted on glass slides, NHM-2000.2059-2062; 4 우 \& 3 ธิ ठ, whole specimens, NHM$2000.2063-2069$.

Body length.-Female: range $=2.20$ $2.46 \mathrm{~mm} ;($ mean $) \pm($ standard deviation $)=$ $2.37 \pm 0.09 \mathrm{~mm}(\mathrm{n}=7)$. Male: range $=2.00$ $2.13 \mathrm{~mm} ; \mathrm{m} . \pm \mathrm{s} . \mathrm{d} .=2.09 \pm 0.05 \mathrm{~mm}(\mathrm{n}=$ $5)$.

Description.-Female. Body (Fig. 1A, B) with prosome approximately 3 times as long as urosome. Fourth and fifth pedigers completely fused; prosome almost symmetrical posteriorly in dorsal and lateral views, with rounded tips not reaching level of genital operculum (Fig.
1C). Urosome (Fig. 1C, D) 2-segmented, with genital compound somite more than half length of urosome; genital compound somite with sinuous lateral margins, bearing small round knob with minute peg-sensillum on left side at midlength; genital operculum located ventrally at tip of swelling in anterior third of compound somite; subterminal portion of compound somite constricted abruptly, possibly indicating secondary fusion between genital compound somite and second original urosomite in former stage (see Fig. 1C); anal somite almost fused to caudal rami with suture distinctly visible; caudal rami asymmetrical, left ramus expanded terminally; right ramus furnished with row of long setules along posterior half of inner margin; caudal seta I rudimentary, seta $\mathrm{V}$ longest, about twice as long as setae III and IV.

Spermatophore attached to female urosome (Fig. 1E, F) with attachment disc covering left lateral and ventral surfaces; spermatophore body, elongate, sausagelike.

Antennule reaching slightly beyond caudal rami (see Fig. 1B); armature elements and fusion pattern typical of subgenus Atortus (see Ohtsuka \& Reid, 1998, Fig. 12). Antenna, mouthparts, and legs 1-4 as in $T$. (A.) ryukyuensis Ohtsuka \& Kimoto, 1989, except for following minute details: mandibular basis with minute prominences at inner midlength (Fig. $1 \mathrm{G}$ ); mandibular exopodal segments almost fused, with 4 transverse rows of spinules (Fig. 1G); maxillary basis with single vestigial element (Fig. $1 \mathrm{H}$, arrowed).

Leg 5 (Fig. 1I, J) with both coxae and intercoxal sclerite fused into common base; basis longer than wide, bearing plumose seta laterally at distal third; exopods asymmetrical, left longer than right, each with bifurcated tip and inner midlength prominence.

Male. Body (Fig. 2A) more slender than that of female; fourth and fifth 


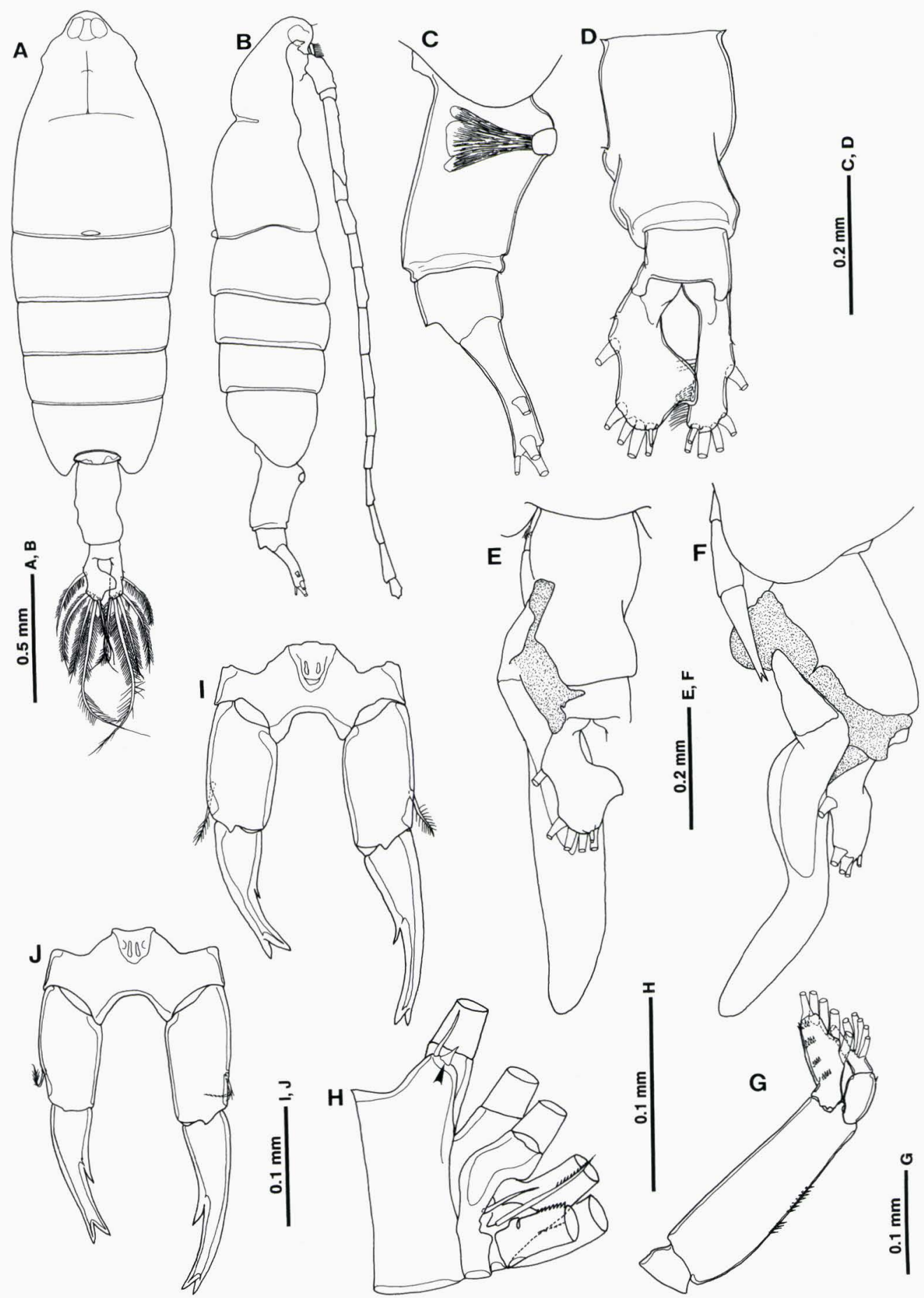

Fig. 1. Tortanus (Atortus) ampliramus new species, female (holotype: A-C, G, H, I; paratypes: D, $\mathrm{E}, \mathrm{F}, \mathrm{J})$ : A, habitus, dorsal view; $\mathrm{B}$, habitus, lateral view; $\mathrm{C}$, urosome, lateral view; D, urosome, dorsal view; E, spermatophore attached to urosome, dorsal view, attachment disc indicated by shaded part; F, spermatophore attached to urosome, lateral view, attachment disc indicated by shaded part; G, mandibular palp; H, maxillary basis and endopod; I, J, leg 5 , anterior surface. 


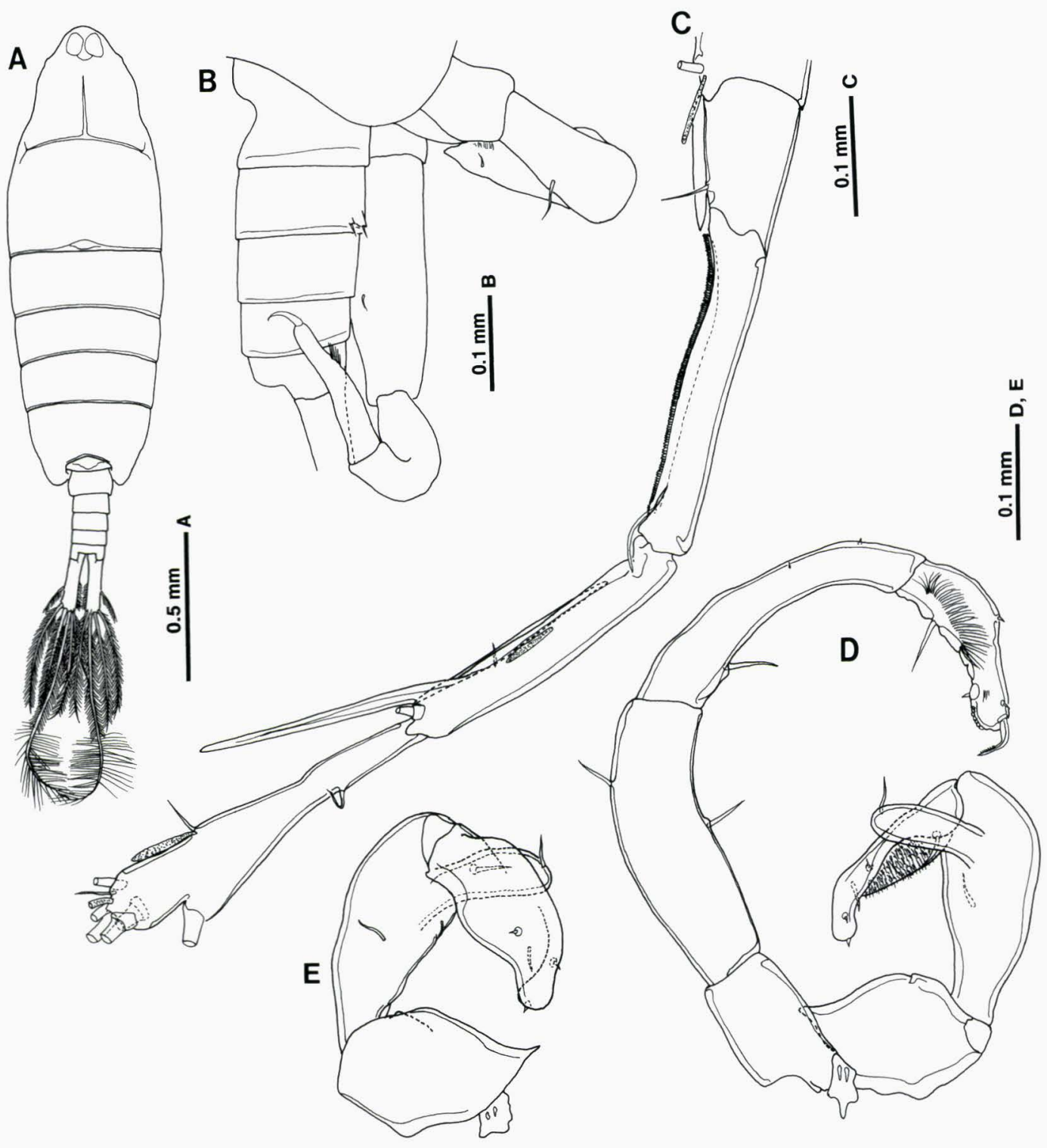

Fig. 2. Tortanus (Atortus) ampliramus new species, male (paratypes): A, habitus, dorsal view; B, urosome and leg 5 , lateral view; C, terminal part of right antennule; D, leg 5, anterior surface; E, right leg 5 , posterior surface.

pedigers completely fused; posterior prosomal ends symmetrical, reaching halfway along genital somite. Urosome (Fig. 2A, B) 5-segmented; genital somite slightly asymmetrical, with left posterior side more expanded than right; second urosomite with 2 ventrolateral pointed protuberances on right side, each bearing peg-sensillum; anal somite almost completely coalescent with caudal rami but with distinct suture; caudal rami symmetrical; caudal seta I minute (not figured in Fig. 2A); caudal seta V longest, about twice as long as setae III and IV, with anterior and posterior halves densely and coarsely plumose, respec- 
tively.

Right antennule (Fig. 2C) with armature elements and fusion pattern typical of Atortus (see Ohtsuka \& Reid, 1998, Fig. 13); spiniform process along anterior margin on segment XIX reaching slightly beyond distal end of segment XX; serrate process on segment XX extending almost entirely along anterior margin of segment; compound segment XXI-XXIII, distal to hinge, with 2 anterior processes, first process reaching near base of distal process, not furnished with serration along anterior margin, second process reaching just to distal end of the compound segment, anterodistal process not reaching base of second seta on compound segment XXIV-XXVIII.

Other appendages except leg 5 as in female. Leg 5 (Fig. 2D, E) similar to that of $T$. (A.) capensis; intercoxal sclerite irregularly modified. Right leg (Fig. 2D, E) with expanded coxa bearing small inner knob near base of basis; basis tapering proximally, with minute seta at midlength on posterior surface and large, linguiform subterminal process (= endopod) bearing fine seta at tip; exopod flattened, bearing patch of fine setules and 2 setae on inner surface, short peg-sensillum on outer surface, and 2 peg-sensilla terminally and subterminally. Left leg (Fig. 2D) with elongate basis bearing 1 inner and 1 outer seta at midlength; exopod 2segmented; first segment as long as basis, curved inwards, bearing inner proximal seta and 2 minute outer peg-sensilla; second segment with row of long setules on anterior surface, 1 inner proximal and 1 terminal seta, and 1 inner subterminal and 2 outer peg-sensilla; terminal portion between terminal seta and inner peg-sensillum carrying row of granules.

Variation.-The expansion of the left caudal ramus of the female more or less varies between individuals. The inner mid-length prominences of the exopod of the female leg 5 are more slender in the holotype than in 2 paratypic females (Fig. $1 \mathrm{~J}, \mathrm{~K})$.

Comaprison.-The new species is assigned to the recticauda species group in the recticauda species complex of the subgenus Atortus in sharing the following characters: the anal somite of the female incompletely fused with the caudal rami; the unisegmented exopod of the female leg 5 tapering distally, with an acute inner process or spine; the right basis of the male leg 5 bearing a large inner process (Ohtsuka \& Kimoto, 1989; Ohtsuka \& Reid, 1998). The species group is distributed exclusively in the western Indian Ocean extending from South Africa (Ohtsuka \& Kimoto, 1989), and now accommodates four species, $T$. (A.) recticauda Giesbrecht, 1889, T. (A.) capensis Grindley, 1978, T. (A.) ampliramus, new species, and T. (A.) nishidai, new species.

The new species is readily distinguished from other members of the recticauda species group by the following characters: (1) the caudal rami of the female are greatly asymmetrical, with the left ramus expanded terminally; (2) the lateral margins of the female genital compound somite are asymmetrically sinuous; (3) the female leg 5 is asymmetrical, with the left exopod longer than the right; (4) the inner process on the right basis of the male leg 5 is located subterminally and rounded at tip; (5) the right exopod of the male leg 5 is flattened.

Remarks.-A simple, sausage-like spermatophore is attached to the genital compound somite of some paratypic females (see Fig. 1E, F). This situation is contrasted with the highly complex spermatophores of Tortanus (Atortus) longipes Brodsky, 1948, T. (A.) bowmani Othman, 1987, and $T$. (A.) ryukyuensis Ohtsuka \& Kimoto, 1989 (see Tanaka, 1965; Othman, 1987; Ohtsuka \& Kimoto, 1989). Females of these species bear a rudimentary, presumably functionless leg 5 . Although Grindley (1978) only mentioned 
that the length of spermatophores of $T$. (A.) capensis is $300-380 \mu \mathrm{m}$, the species with the well-developed female leg 5 also seems to have a simple sausage-like spermatophore as does $T$. (A.) ampliramus. The functional morphology of spermatophores in Tortanus is discussed below.

Epizoic tube-forming pennate diatoms are attached on the anal somite in the holotype and two paratypic males.

Etymology.-The specific name is derived from the Latin amplius, meaning broad and the Latin ramus, meaning branch, and refers to the expanded terminal portion of the left caudal ramus of the female.

\section{Tortanus (Atortus) nishidai new species}

Fig. 3

Material examined. $-2 \delta^{\star} \delta$, off South Yemen in the Gulf of Aden $\left(13^{\circ} 45^{\prime} \mathrm{N}\right.$, 46³5’E), December 18, 1979.

Types.-Holotype: 1 , partly dissected and mounted on glass slides, NHM-2000.2070. Paratype: 1 o, partly dissected and mounted on glass slides, NHM-2000.2071

Body length.-Male: holotype 1.53 $\mathrm{mm}$; paratype $1.57 \mathrm{~mm}$.

Description.-Male. Body (Fig. 3A) resembling that of male of Tortanus (Atortus) ampliramus, new species described above, except for details of urosome: 2 right ventrolateral setules on second urosomite relatively long, reaching midlength of next urosomite (Fig. 3C); caudal rami tapering proximally; caudal seta V relatively short, ornamented almost equally along whole length.

Right antennule as in male of $T$. (A.) ampliramus except for following features (Fig. 3D): proximal process on compound segment XXI-XXIII with distinctly serrate anterior margin, serration reaching midway at most, distal process without serration, reaching slightly beyond distal end of segment, anterodistal process elongate, reaching beyond base of third seta on terminal compound segment XXIVXXVIII.

Other mouth appendages and legs 1-4 similar to those of $T$. (A.) ryukyuensis (Ohtsuka \& Kimoto, 1989); maxillary basis with 1 rudimentary element as in $T$. (A.) ampliramus.

Leg 5 (Fig. 3E-H) with irregular, rudimentary intercoxal sclerite. Right leg (Fig. 3E, H) with coxa produced medially into rectangular process; basis constricted proximally, bearing minute seta at midlength on posterior surface; endopod, represented by round flattened process, located at inner distal corner of basis; endopod adorned with 1 subterminal and 1 posterior seta; exopod smoothly curved inward, tapering distally into pointed tip, with lamellar plate along outer proximal half length. Left leg (Fig. 3E, F, G) with coxa relatively short; basis bearing fine seta on low inner middle projection with broad base and minute setule at distal fourth of outer margin; first exopodal segment with round inner proximal process carrying subterminal setule; second exopodal segment abruptly curved inward at midlength; patch of minute prominences present between terminal and inner subterminal spiniform setae.

Female unknown.

Variation.-Significant variation was not found in the fifth legs of the two specimens examined.

Comparison.-The new species is definitely assigned to the recticauda species group, and closely resembles $T$. capensis in the structure of the male leg 5 . The new species is distinguishable by the following characters of the male leg 5: (1) the right coxa bears a rectangular process in $T$. nishidai, while rounded in T. capensis; (2) the right endopod has a rounded tip, compared with bilobed apex in $T$. capensis.

Remarks.-The new species was re- 


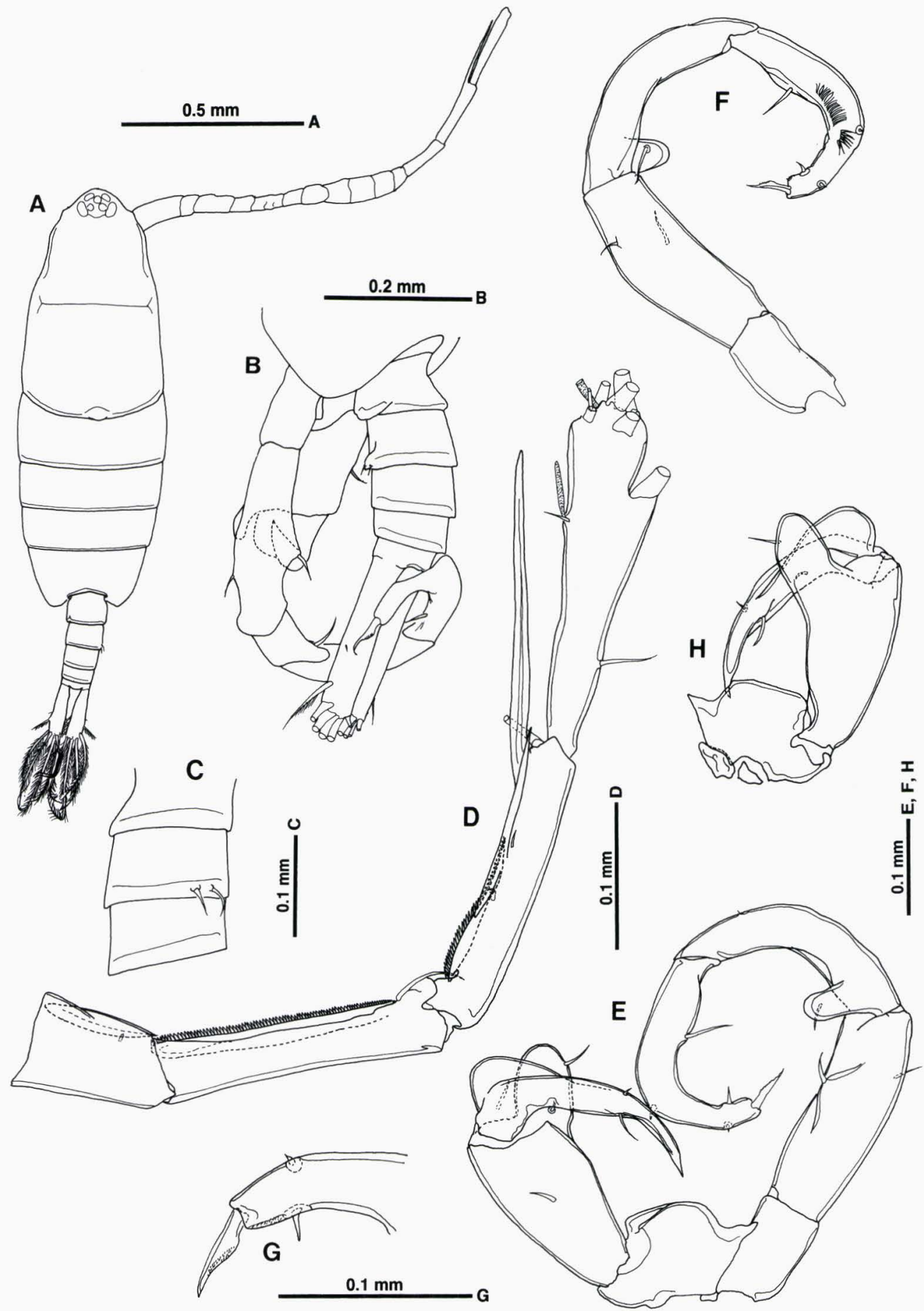

Fig. 3. Tortanus (Atortus) nishidai new species, male (holotype: A-E, G; paratype: F, H): A, habitus, dorsal view; $\mathrm{B}$, urosome and leg 5 , lateral view; $\mathrm{C}$, first three urosomites, lateral view; $\mathrm{D}$, terminal part of right antennule; $\mathrm{E}$, leg 5 , posterior surface; $\mathrm{F}$, left leg 5 , anterior surface; $\mathrm{G}$, terminal part of left leg 5 , posterior surface; $H$, right leg 5 , anterior surface. 
ferred to as Tortanus sp. in Ohtsuka \& Kimoto (1989) without descriptions and illustrations. A simple, sausage-like spermatophore was observed in the vas-deferens in the holotypic male.

Etymology.-The specific name is named in honor of Dr. Shuhei Nishida (The Ocean Research Institute, the University of Tokyo) who kindly provided us with the specimens.

\section{Note on Tortanus (Atortus) taiwanicus Chen \& Hwang, 1999}

Tortanus (Atortus) taiwanicus was described from the coastal waters of Hualien, Taiwan by Chen \& Hwang (1999). This species can be assigned to the rubidus species group in the brevipes species complex, on the basis of the definition given by Ohtsuka \& Kimoto (1989): brevipes species complex: male second urosomite with elongate process on right side; serrate process on segment XVIII of right antennule of male extended proximally over preceding segment; rubidus species group: posterior corners of female prosome asymmetrical; leg 5 of female rudimentary, 2-segmented with terminal lamellate segment bearing single seta; posterior corners of male prosome symmetrical; proximal process of segment XIX of right antennule of male extending over half of segment; right coxa of male leg 5 with inner subterminal process; right basis of male leg 5 bearing broad inner projection; unisegmented right exopod of male leg 5 as long as basis; first exopod segment of left leg 5 of male with inner cylindrical process proximally.

\section{Discussion}

Functional morphology of spermatophores

The morphology of spermatophores of the genus Tortanus is known from the subgenera Tortanus, Eutortanus, Atortus, and Boreotortanus (Tanaka, 1965; Othman, 1987; Ohtsuka \& Kimoto, 1989; Ohtsuka et al., 1995; Ohtsuka \& Reid, 1998; present study; Ohtsuka, personal observation). There are two basic types of spermatophores in the genus: (1) sausagelike spermatophore with a simple attachment disc; (2) highly complex spermatophore with a complicated coupler covering the female urosome almost entirely. The first type is common in most calanoids (Blades-Eckelbarger, 1991), and is found in the subgenera Tortanus, Eutortanus, Atortus, and Boreotortanus. The second type is found in some species of Atortus and Eutortanus. In Atortus species belonging to the recticauda species complex with a well-developed female leg 5 are assigned to the first type, whereas species in the rubidus species group with a rudimentary (functionless) female leg 5 belongs to the second type.

Recently Ohtsuka \& Huys (in press) have suggested that the second type of spermatophore is persistent, remaining to the female genital compound somite until the final clutch of eggs is released, and that eggs are released from an opening on the ventral side of the spermatophore, beneath which the genital operculum is located. In most taxa of the superfamily Centropagoidea including Tortanus, there are no seminal receptacles in the female (Barthélémy et al., 1998; Barthélémy, 1999). Therefore multiple matings are normally needed to fertilize all clutches of eggs throughout the life of the female (Barthélémy et al., 1998; Barthélémy, 1999). On the other hand, the second type of spermatophore in Tortanus may contain sufficient spermatozoa to fertilize all clutches of eggs. Complex couplers are found also in other centropagoids such the genera Centropages (Centropagidae) and Labidocera (Pontellidae) (BladesEckelbarger, 1991). However these females bear a well-developed leg 5 so that empty spermatophores are likely to be mechanically (and, in some cases chemically) detached from the genital compound somite (Blades-Eckelbarger, 1991).

The second type of spermatophore is 
interesting from genetic and evolutionary points of view. Once a spermatophore is transferred from the male to the female and attached, no more copulation may occur. The coupler may correspond to "mating plugs" found in many insects and mammals, which are left on the female's genital tract after copulation in order to prevent subsequent copluation by other males (cf. Krebs \& Davies, 1978). A male which succeeds in transferring a spermatophore to a female can monopolise her to propagate his own genes: he meets "intrasexual competition" (Krebs \& Davies, 1978) successfully. Couplers of some species of Atortus are utilized not only for the conspecific recognition (Blades-Eckelbarger, 1991) but also for the propagation of specific genes. Such a semelparous reproductive strategy is rarely known in centropagoidean copepods. The fine structure of the complex coupler of Atortus will be accounted in detail in our forthcoming paper (Ohtsuka et al., in preparation).

\section{Behavioral ecology}

Aggregations, swarms, and schools are known in planktonic copepods in both shallow and deep waters (Humes \& Smith, 1974; Hamner \& Carleton, 1979; Fleminger, 1983; Ueda et al., 1983; Kimoto et al., 1988; Mauchline, 1998). In Tortanus, swarming behavior is reported exclusively in some species of the subgenus Atortus that prefer oligotrophic clear waters mainly in subtropical and tropical areas (Kimoto et al., 1988; Ohtsuka \& Kimoto, 1989; Ohtsuka \& Reid, 1998). Ohtsuka \& Reid (1998) have speculated that this behavior has evolved as an antipredation strategy against visual predators in highly transparent waters, since in other subgenera inhabiting turbid brackish and neritic waters, such swarming behavior has never been observed.

In the subgenus Atortus swarm formations have hitherto been observed in three species occurring in Japanese waters, i.e., T. (A.) longipes Brodsky, 1948, T. (A.) rubidus Tanaka, 1965, and $T$. (A.) erabuensis (Kimoto et al., 1988; Ohtsuka \& Kimoto, 1989; Ohtsuka \& Nishida, 1997; Ohtsuka et al., unpublished data). Multispecies swarms composed of the former two species were observed above sandy and rocky bottoms and inside eelgrass beds at depths of $2-6 \mathrm{~m}$ in a small inlet Shijiki Bay, western Japan (Kimoto et al., 1988; Ohtsuka \& Kimoto, 1989). The swarms consisted of adult and copepodid stages, and the density was much higher in $0-20 \mathrm{~cm}$ layer above the bottom than in $20-40 \mathrm{~cm}$ layer, ranging from 26 to 274 individuals $\mathrm{m}^{-3}$ in the $0-20$ cm layer (Ohtsuka \& Kimoto, 1989).

Five monospecific swarms of $T$. (A.) erabuensis were observed at depths of 2-4 $\mathrm{m}$ in a small inlet of Kuchinoerabu Island, southwestern Japan on September 7, 1989. All swarms were formed around large rocks of about 1-3 $\mathrm{m}$ in dimension, inside or contiguous with larger swarms of another small copepod, Oithona oculata Farran, 1913. Tortanus swarms were either irregular spheres with $30-50 \mathrm{~cm}$ in diameter or column-like with $30 \mathrm{~cm}$ in diameter and $60 \mathrm{~cm}$ in height, and consisted mainly of the fourth (CIV) and fifth (CV) copepodid stages (>95\%). Adults formed less than $5 \%$ of the total. No early copepodid stages, such as CI and CII were involved. The density of all copepodid stages in a swarm of $T$. (A.) erabuensis ranged approximately from 4 to 22 individuals $\mathrm{l}^{-1}$. Tortanus swarms were likely to have attacked those of $O$. oculata for food, based on our in-situ visual observations and gut content analyses (Ohtsuka et al., 1987; Ohtsuka et al., unpublished data). Tortanus is known to be a typical carnivore feeding on copepods and other zooplankters (Anraku \& Omori, 1963; Ambler \& Frost, 1974; Mullin, 1979; Ohtsuka et al., 1987; Ohtsuka, 1991). Since the co-occurrence of swarms of the predators and their prey copepods such as 
Acartia and Oithona is reported also in Japan and Australia (Ohtsuka et al., 1987; Ohtsuka \& Kimoto, 1989; McKinnon, 1993), Atortus may form a swarm as a response to the presence of prey copepod swarms. The early copepodid stages (CI and CII) of $T$. (A.) erabuensis might have avoided entering swarms, because these stages are almost equal to or smaller than adults of the prey copepod, $O$. oculata and are likely to be preyed upon by the later stages of the same species (cannibalism). This hypothesis is supported by a fact that swarms of predatory calanoids, Tortanus (Atortus) spp. and Labidocera pavo (cf. Ohtsuka \& Onbé, 1991) were composed exclusively of CIV-VI (Ueda et al., 1983; Kimoto et al., 1988). Since stage-specificity is known in many copepod swarms (Byron et al., 1983; Fleminger, 1983; Ueda et al., 1983), there could be some biological mechanisms for the maintenance. Swarming in Atortus may function, not only as an antipredation strategy, but also a foraging strategy.

According to the phylogeny of the genus Tortanus proposed by Ohtsuka \& Reid (1998), the subgenus Atortus is one of the most advanced groups of the five subgenera. This subgenus seems to have succeeded in acquiring not only morphological novelties but also new reproductive and behavioral strategies that are not seen in other subgenera.

\section{Acknowledgments}

We wish to express our sincere thanks to Drs Janet Bradford-Grieve and Geoffrey A. Boxshall for critical reading of the early draft. We are also grateful to Dr. $M$. Hanafy for his support and encouragement. Thanks are due to Dr Atsushi Tsuda and the captain and crew of a research vessel, Tankai-maru for providing us with a female of Tortanus (Boreotortanus) discaudatus with a spermatophore on the genital compound somite. This work was supported in part by a Grant-in-Aid of the Ministry of Education, Science, Sports and Culture of Japan to SO (No. 10660180).

\section{Literature Cited}

Anraku, M., \& Omori, M., 1963. Preliminary survey of the relationship between the feeding habit and the structure of the mouth-parts of marine copepods. Limnology and Oceanography, 8: 116-126.

Ambler, J. W., \& Frost, B. W., 1974. The feeding behavior of a predatory planktonic copepod, Tortanus discaudatus. Limnology and Oceanography, 19: 446-451.

Barthélémy, R.-M., 1999. Functional morphology and taxonomic relevance of the female genital structures in Acartiidae (Copepoda: Calanoida). Journal of the Marine Biological Association of the United Kingdom, 79: 857-870.

, Cuoc, C., Defaye, D., Brunet, M., \& Mazza, J., 1998. Female genital structures in several families of Centropagoidea (Copepoda: Calanoida). Philosophical Transactions of the Royal Society of London, B, 353: 1-16.

Blades-Eckelbarger, P. I. 1991. Functional morphology of spermatophores and sperm transfer in calanoid copepods. In: R. T. Bauer \& J. W. Martin (eds), Crustacean Sexual Biology: 246-270.

Bowman, T. E., 1986. Tortanus recticauda: extension of range to Arabian Gulf (Copepoda, Calanoida, Tortanidae). Crustaceana, 50: 239-242.

Byron, E. R., Whitman, P. T., \& Goldman, C. R., 1983. Observations of copepod swarms in Lake Tahoe. Limnology and Oceanography, 28: 378-382.

Chen, Q.-C., \& Hwang, J.-S., 1999. A new species of Tortanus (Copepoda, Calanoida) from Taiwan. Crustaceana, 72: 265-271.

Fleminger, A., 1983. Description and phylogeny of Isaacsicalanus paucisetus, n. gen., $\mathrm{n}$. sp., (Copepoda: Calanoida: Spinocalanidae) from an East Pacific hydrothermal vent site $\left(21^{\circ} \mathrm{N}\right)$. Proceedings of the Biological Society of Washington, 96: 605-622.

Grindley, J. R., 1978. A new species of Tortanus (Crustacea, Copepoda) from South Africa. The Annals of the South African Museum, 74: 219-228.

Hamner, W. M., \& Carleton, J. H., 1979. Copepod swarms: attributes and role in coral reef ecosystems. Limnology and Oceanog- 
raphy, 24: 1-14.

Humes, A., \& Smith, W. L., 1974. Ridgewayia fosshageni n. sp. (Copepoda; Calanoida) associated with an actiniarian in Panama, vith [sic] observations on the nature of the association. Caribbean Journal of Science, 14: 125-139.

Huys, R., \& Boxshall, G. A., 1991. Copepod Evolution. 468 pp., The Ray Society, London.

Kimoto, K., Nakashima, J., \& Morioka, Y., 1988. Direct observations of copepod swarm in a small inlet of Kyushu, Japan. Bulletin of the Seikai Regional Fisheries Research Laboratory, 66: 41-58.

Krebs, J. R., \& Davies, N. B., 1978. Behavioural Ecology, 494 pp., Blackwell Scientific Publications, Oxford.

Mauchline, J., 1998. The biology of calanoid copepods. Advances in Marine Biology, 33: 1-707.

McKinnon, A. D., 1993. A variant form of Tortanus scaphus Bowman, 1971 from Davies Reef, North Queensland. Proceedings of the Royal Society of Queensland, 103: $1-3$.

Mullin, M. M., 1979. Differential predation by the carnivorous marine copepod, Tortanus discaudatus. Limnology and Oceanography, 24: 774-777.

Ohtuska, S., 1991. Structure and function of the mouthparts of calanoid copepods of the Seto Inland Sea and its environs, with special reference to their in-situ feeding habits. PhD. thesis, University of Tokyo, Tokyo.

, \& Huys, R., in press. Sexual dimorphism in calanoids-morphology and function. Hydrobiologia.

— \& Kimoto, K., 1989. Tortanus (Atortus) (Copepoda: Calanoida) of southern Japanese waters, with description of two new species and notes on distribution and swarming behavior of Atortus. Journal of Crustacean Biology, 9: 392-408.

, \& Nishida, S., 1997. Reconsideration on feeding habits of marine copepods (Crustacea). Umi no kenkyu, 6: 299-320. (In Japanese with English abstract)
\& Onbé, T., 1991. Relationship between mouthpart structures and in situ feeding habits of species of the family Pontellidae. Marine Biology, 111: 213-225. \& Reid, J. W., 1998. Phylogeny and zoogeography of the planktonic copepod genus Tortanus (Calanoida: Tortanidae), with establishment of a new subgenus and descriptions of two new species. Journal of Crustacean Biology, 18: 774-807.

—, Fukuura, Y., \& Go, A., 1987. Description of a new species of Tortanus (Copepoda: Calanoida) from Kuchinoerabu Island, Kyushu, with notes on its possible feeding mechanism and in-situ feeding habits. Bulletin of Plankton Society of Japan, 34: 53-63.

—, Ueda, H., \& Lian, G.-S., 1995. Tortanus derjugini Smirnov (Copepoda: Calanoida) from the Ariake Sea, western Japan, with notes on the zoogeography of brackish-water calanoid copepods in East Asia. Bulletin of Plankton Society of Japan, 42: 147-162.

Othman, B. H. R., 1987. Two new species of Tortanus (Crustacea, Copepoda) from Sabah, Malaysia. Malayan Nature Journal, 41: 61-73.

Tanaka, O., 1965. The pelagic copepods of the Izu region, Middle Japan. Systematic account XIII. Parapontellidae, Acartiidae and Tortanidae. Publications of the Seto Marine Biological Laboratory, 12: 379-408.

Ueda, H., Kuwahara, A., Tanaka, M., \& Azeta, M., 1983. Underwater observations on copepod swarms in temperate and subtropical waters. Marine Ecology Progress Series, 11: 165-171.

Addresses: (SO) Fisheries Laboratory, Hiroshima University, 5-8-1 Minato-machi, Takehara, Hiroshima 725-0024, Japan; (MME) Marine Science Department, Faculty of Science, Suez Canal University, Ismailia, Egypt; (HU) Center for Marine Environmental Studies, Ehime University, 3 Bunkyo-cho, Matsuyama, Ehime 790-8577, Japan.

E-mail: (SO) ohtsuka@hiroshima-u.ac.jp 